\title{
Postnatal expression of transport proteins involved in acid?base transport in mouse kidney
}

\author{
Bonnici, Brenda ; Wagner, Carsten A
}

\begin{abstract}
The kidney plays a major role in maintaining and controlling systemic acid-base homeostasis by reabsorbing bicarbonate and secreting protons and acid-equivalents, respectively. During postnatal kidney development and adaptation to changing diets, plasma bicarbonate levels are increasing, the capacity for urinary acidification maturates, and the final morphology and distribution of intercalated cells is achieved. In adult kidney, at least two types of intercalated cells (IC) are found along the collecting duct characterised either by the expression of AE1 (type A IC) or pendrin (non-type A IC) where nontype A IC are found only in the convoluted distal tubule, connecting tubule and cortical collecting duct. Here we investigated in mouse kidney the relative mRNA abundance, protein expression levels and distribution of several proteins involved in renal acid-base transport, namely, the Na+/HCO3 cotransporter NBC1 (SLC4A4), the Na+/H+-exchanger NHE3 (SLC9A3), two subunits of the vacuolar $\mathrm{H}+$-ATPase [ATP6V0A4 (a4), ATP6V1B1 (B1)], the Cl-/HCO3 - exchangers AE1 (SLC4A1) and pendrin (SLC26A4). Relative mRNA abundance of all transport proteins was lowest at day3 after birth and increased thereafter in parallel with protein levels. The numbers of type A and non-type A IC in the cortical collecting duct (CCD) increased from day3 to days18 and 24, whereas the number of IC in the CCD with apical staining for the vacuolar H+-ATPase subunits a4 and B1 decreased from day3 to days18 and 24, respectively. In addition, cells with characteristics of non-type A IC (pendrin expression, basolateral expression of vacuolar $\mathrm{H}+$-ATPase subunits) were found in the inner and outer medulla 3 days after birth but were absent from the medulla of 24-day-old mice. Taken together, these results demonstrate massive changes in mRNA and protein expression levels of several acid-base transporters during postnatal kidney maturation and also show changes in intercalated cell phenotype in the medulla during these processes
\end{abstract}

DOI: https://doi.org/10.1007/s00424-003-1227-4

Posted at the Zurich Open Repository and Archive, University of Zurich

ZORA URL: https://doi.org/10.5167/uzh-156550

Journal Article

Published Version

Originally published at:

Bonnici, Brenda; Wagner, Carsten A (2004). Postnatal expression of transport proteins involved in acid?base transport in mouse kidney. Pflügers Archiv : European Journal of Physiology, 448(1):16-28.

DOI: https://doi.org/10.1007/s00424-003-1227-4 


\section{Brenda Bonnici · Carsten A. Wagner \\ Postnatal expression of transport proteins involved in acid-base transport in mouse kidney}

Received: 18 October 2003 / Revised: 24 November 2003 / Accepted: 1 December 2003 / Published online: 31 January 2004 (C) Springer-Verlag 2004

\begin{abstract}
The kidney plays a major role in maintaining and controlling systemic acid-base homeostasis by reabsorbing bicarbonate and secreting protons and acidequivalents, respectively. During postnatal kidney development and adaptation to changing diets, plasma bicarbonate levels are increasing, the capacity for urinary acidification maturates, and the final morphology and distribution of intercalated cells is achieved. In adult kidney, at least two types of intercalated cells (IC) are found along the collecting duct characterised either by the expression of AE1 (type A IC) or pendrin (non-type A IC) where non-type A IC are found only in the convoluted distal tubule, connecting tubule and cortical collecting duct. Here we investigated in mouse kidney the relative mRNA abundance, protein expression levels and distribution of several proteins involved in renal acid-base transport, namely, the $\mathrm{Na}^{+} / \mathrm{HCO}_{3}{ }^{-}$cotransporter $\mathrm{NBC1}$ (SLC4A4), the $\mathrm{Na}^{+} / \mathrm{H}^{+}$-exchanger NHE3 (SLC9A3), two subunits of the vacuolar $\mathrm{H}^{+}$-ATPase [ATP6V0A4 (a4), ATP6V1B1 (B1)], the $\mathrm{Cl}^{-} / \mathrm{HCO}_{3}{ }^{-}$exchangers AE1 (SLC4A1) and pendrin (SLC26A4). Relative mRNA abundance of all transport proteins was lowest at day 3 after birth and increased thereafter in parallel with protein levels. The numbers of type A and non-type A IC in the cortical collecting duct (CCD) increased from day 3 to days 18 and 24, whereas the number of IC in the CCD with apical staining for the vacuolar $\mathrm{H}^{+}$-ATPase subunits a4 and B1 decreased from day 3 to days 18 and 24, respectively. In addition, cells with characteristics of nontype A IC (pendrin expression, basolateral expression of vacuolar $\mathrm{H}^{+}$-ATPase subunits) were found in the inner and outer medulla 3 days after birth but were absent from the medulla of 24-day-old mice. Taken together, these results demonstrate massive changes in mRNA and protein
\end{abstract}

\footnotetext{
B. Bonnici · C. A. Wagner $(\bowtie)$

Institute of Physiology, University of Zurich,

Winterthurerstr. 190,

8057 Zurich, Switzerland

e-mail: wagnerca@access.unizh.ch

Tel.: +41-1-63-55032

Fax: +41-1-63-56814
}

expression levels of several acid-base transporters during postnatal kidney maturation and also show changes in intercalated cell phenotype in the medulla during these processes.

Keywords Acid-base transport - Protein expression . Kidney $\cdot$ Intercalated cells

\section{Introduction}

Together with respiration, the kidney is essential in controlling acid-base homeostasis. The proximal tubule is responsible for the reabsorption of about $80 \%$ of filtered bicarbonate $[6,14,40]$, and contains among other acidbase transporters on the apical side, the $\mathrm{Na}^{+} / \mathrm{H}^{+}$exchanger NHE3 (SLC9A3), vacuolar $\mathrm{H}^{+}$-ATPases and on the basolateral membrane the $\mathrm{Na}^{+} / \mathrm{HCO}_{3}{ }^{-}$cotransporter NBC1 (SLC4A4). Both NHE3 and vacuolar $\mathrm{H}^{+}$-ATPases are responsible for $\mathrm{H}^{+}$secretion mediating the first step of $\mathrm{HCO}_{3}{ }^{-}$reabsorption [14], whereas $\mathrm{NBC} 1$ is expressed on the basolateral membrane of the proximal tubule and extrudes $\mathrm{HCO}_{3}{ }^{-}$into the peritubular interstitium $[14,34]$. Fine regulation of acid-base excretion and absorption occurs in the connecting tubule (CNT), the cortical collecting duct (CCD) and outer medullary collecting duct (OMCD) [14, 47]. The CNT and CCD either reabsorb or secrete $\mathrm{H}^{+}$and $\mathrm{HCO}_{3}^{-}$, respectively, whereas the OMCD secretes only $\mathrm{H}^{+}[14,47]$. At least three cell types are present in the collecting duct: principal cells, type A intercalated cells and non-type A intercalated cells. Principal cells comprise about two-thirds of the cells in the CNT and CCD $[22,43]$ and are characterised by their expression of the AQP2 water channel protein [32].

Intercalated cells are the main cells involved in acidbase transport along the collecting duct and they are present in CNT, CCD, OMCD and the initial third of the inner medullary collecting duct (IMCD) [22, 27, 43, 47]. Based on morphological and functional characteristics, at least two types of intercalated cells may be distinguished: type A and non-type A intercalated cells. Some authors 
have subdivided the non-type A intercalated into two subtypes: type B cells and non-A-non-B cells (or $\gamma$-cells) characterised by bipolar or apical vacuolar $\mathrm{H}^{+}$-ATPase expression, respectively, in the absence of positive staining for the $\mathrm{Cl}^{-} / \mathrm{HCO}_{3}{ }^{-}$exchanger AE-1 [12, 22, 43, 47]. Type A intercalated cells secrete $\mathrm{H}^{+}$into urine and release $\mathrm{HCO}_{3}{ }^{-}$in exchange for $\mathrm{Cl}^{-}$into the peritubular interstitium, and can be identified by the presence of $\mathrm{H}^{+}$-ATPase on the apical plasma membrane and a band 3-like $\mathrm{Cl}^{-} /$ $\mathrm{HCO}_{3}{ }^{-}$exchanger AE1 (SLC4A1) on the basolateral plasma membrane $[1,22,37,43]$. In contrast, non-type A intercalated cells secrete bicarbonate into urine, and show a basolateral or bipolar expression of the vacuolar $\mathrm{H}^{+}$ATPase and an apical $\mathrm{Cl}^{-} / \mathrm{HCO}_{3}{ }^{-}$exchanger, possibly pendrin (SLC6A4) [35, 46, 49]. Type A cells are found in the CNT, CCD, OMCD and initial IMCD, whereas nontype A cells are present only in the CNT and CCD [25].

During pre- and postnatal kidney development, maturation of both morphology and functional transport processes occurs as demonstrated for several ion channels and proteins involved in electrolyte and acid-base transport $[6,16,17,18,40,44]$. In newborns, nephrogenesis is not complete and plasma $\mathrm{HCO}_{3}{ }^{-}$is lower than that of adults $[6,11,45]$. This is thought to be partly due to renal tubular immaturity to reabsorb $\mathrm{HCO}_{3}^{-}$[11] or to a state of relative volume expansion in early life [45]. Accordingly, in rabbit neonates, it has been found that NHE3 activity in the proximal tubule is one-third of that in adult and no vacuolar $\mathrm{H}^{+}$-ATPase activity has been found $[3,6]$. After birth, carbonic anhydrase IV abundance and activity increase as a prerequisite for urinary acidification in both the proximal tubule and medullary collecting duct $[39$, 50]. Similarly, in rats, carbonic anhydrase II in the initial segment of the proximal tubule and in the CCD and OMCD increases in parallel during the first weeks of life [19].

During fetal development when intercalated cells (IC) first appear, the cells in the CCD are not yet fully differentiated [20]. It is thought that type A and non-type A IC differentiate prenatally from precursor cells both in the CNT and medullary collecting duct. Using electron microscopy and morphological criteria, Kim et al. have shown that in the rat OMCD, there is gradual disappearance of non type-A cells from 1 to 3 weeks after birth [20]. To the contrary, the percentage of type-A IC in rat OMCD increased during the first 3 postnatal weeks [20].

The aim of the present study was to investigate the postnatal mRNA and protein expression levels of several proteins involved in renal acid-base transport. In addition, we examined the localisation and relative abundance of type A and non-type A IC during the first 3 weeks after birth in mouse kidney. We focused on expression of transport proteins in the proximal tubule, the main site of $\mathrm{HCO}_{3}{ }^{-}$reabsorption, and in the collecting duct, the site of fine regulation of final urinary acidification. Three time points were chosen: 3,18 and 24 days after birth where 18 and 24 days represent time points when kidney maturation is thought to be mostly completed but where a further change in diet occurs during weaning at day 21 . Our results demonstrate the postnatal maturation of several transport pathways involved in acid-base transport and changes in the expression pattern of IC over this period of time.

\section{Methods}

Urine and blood analysis

Male C57BL/6 J mice (3 days, 18 days and 24 days old) were anaesthetised with ketamine-xylazine, and urine and blood was collected. Urine samples were collected from the urinary bladder: $\mathrm{pH}$, creatinine, $\mathrm{K}^{+}, \mathrm{Na}^{+}$and $\mathrm{Cl}^{-}$concentrations measured. The $\mathrm{pH}$ was measured immediately after collecting urine using a $\mathrm{pH}$ microelectrode (PHR-146 Lazar, Lazar, Los Angeles, Calif.) connected to a $\mathrm{pH}$ meter (Thermo Orion model 290, Orion, Boston, Mass.), the samples were then diluted 1:1 with deionised water and $\mathrm{K}^{+}, \mathrm{Na}^{+}$and $\mathrm{Cl}^{-}$concentrations were measured using a blood-gas analyser (ABL 505, Radiometer, Copenhagen, Denmark). Creatinine in urine was measured using a commercial creatinine kit (Sigma, St. Louis, Mo.). Blood was taken from the vena cava of 18 and 24-day-old mice and blood gases, $\mathrm{K}^{+}, \mathrm{Na}^{+}$and $\mathrm{Cl}^{-}$concentrations were measured using a blood-gas analyser (ABL 505). Creatinine in serum was measured using an enzymatic kit (Wako, Neuss, Germany). Blood analysis was not performed on 3-day-old mice because of difficulties in obtaining large enough sample volumes.

\section{Real-time PCR}

Male C57BL/6 J mice (3 days, 18 days and 24 days) were sacrificed and the kidneys were rapidly removed, frozen and stored at $-80^{\circ} \mathrm{C}$ until further use.

\section{$R N A$ extraction}

RNA was extracted from kidney using the RNeasy Microtest Kit (Qiagen, Cologne, Germany). The tissue was thawed in RNALater solution (Ambion, Austin, Tex.). About $10 \mathrm{mg}$ of kidney was homogenised on ice according to manufacturer's instructions. Quantity and purity of total RNA were assessed by spectrometry and on agarose gels, respectively.

\section{Reverse transcription and PCR}

Each RNA sample was diluted to $100 \mathrm{ng} \mu \mathrm{l}^{-1}$ and $1 \mu \mathrm{l}$ was used as the template for reverse transcription using the Taqman Reverse Transcription kit (Applied Biosystems). The thermal cycle conditions used were $25^{\circ} \mathrm{C}(10 \mathrm{~min}), 48^{\circ} \mathrm{C}(30 \mathrm{~min})$ and $95^{\circ} \mathrm{C}(5 \mathrm{~min})$. Primers and probes were designed using Primer Express (Applied Biosystems) and purchased from Microsynth, Switzerland (Table 1). The specificity of the primers was tested by conventional PCR using adult mouse kidney RNA. Each pair of primers resulted only in a single band of the expected size (data not shown). Probes were labelled with the reporter dye FAM at the $5^{\prime}$ end and the quencher dye TAMRA at the $3^{\prime}$ end. RT-PCR reactions were performed using Taqman Universal PCR Master Mix (Applied Biosystems). Reaction volumes of $25 \mu \mathrm{l}$ were prepared using $1 \mu \mathrm{l}$ of RNA template. Optical reaction plates (96-well) and caps (Applied Biosystems) were used with the Plate type 7700 Single reporter dye. Thermal cycles were set at $50^{\circ} \mathrm{C}(2 \mathrm{~min}), 95^{\circ} \mathrm{C}(10 \mathrm{~min})$ and then 40 cycles at $95^{\circ} \mathrm{C}(15 \mathrm{~s})$ and $60^{\circ} \mathrm{C}(1 \mathrm{~min})$. Each reaction was carried out in triplicate and the average taken. Only results with less than 1 cycle difference were taken into consideration. Cross-point threshold $\left(C_{\mathrm{t}}\right.$ 
value) was taken as the earliest cycle number in the PCR amplification when fluorescence rises significantly above the background fluorescence. Each gene was quantified using GAPDH as the reference gene.

\section{Data analysis}

Data analysis was performed as described previously [33]. For standard curves, serial dilutions of $200 \mathrm{ng} \mu \mathrm{l}^{-1}, 100 \mathrm{ng} \mu \mathrm{l}^{-1}$,

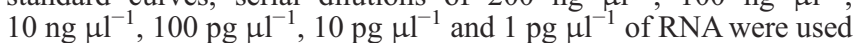
for $25 \mu \mathrm{l}$ reactions (in triplicate). Standard curves were calculated for each gene. Average cycle numbers were plotted against log quantity and the slope calculated. The efficiency was calculated using the following equation: efficiency $(E)=10^{(-1 / \text { slope })}$. The relative expression ratio $(R)$ to determine the relative quantification of the target gene in comparison to the reference gene $(\mathrm{GAPDH})$ was calculated using: $R=\left(E_{\text {target }}\right)^{\wedge} \Delta C_{\mathrm{p} \text {,target }}$ (control-sample $) /\left(E_{\text {reference }}\right)$ $\wedge \Delta C_{\mathrm{p}, \text { reference }}$ (control-sample), where $\Delta C_{\mathrm{p}}$ is the difference in the cycle number values, $E_{\text {target }}$ is the efficiency calculated for the gene of interest, $E_{\text {reference }}$ is the efficiency calculated for the reference gene (GAPDH), $\Delta C_{\mathrm{p}}$ is the deviation of control-sample, control is the result for the gene of interest in adult kidney, sample is the result obtained for the gene of interest in experimental conditions.

\section{Western blot}

Male C57BL/6 J mice (3 days, 18 days and 24 days) were sacrificed and the kidneys perfused with sucrose-phosphate buffer (sucrose $140 \mathrm{mM}, \mathrm{NaH}_{2} \mathrm{PO}_{4} 28 \mathrm{mM}, \mathrm{Na}_{2} \mathrm{HPO}_{4} 112 \mathrm{mM}$; pH 7.4) and rapidly removed. The kidneys were homogenised in ice-cold K-HEPES buffer (200 mM mannitol, $80 \mathrm{mM}$ K-HEPES, $41 \mathrm{mM} \mathrm{KOH,} \mathrm{pH} \mathrm{7.5)}$ with pepstatin, leupeptin, K-EDTA and PMSF added as protease inhibitors. The samples were homogenised with a sonicator, centrifuged at $1,000 \mathrm{~g}$ for $10 \mathrm{~min}$ at $4^{\circ} \mathrm{C}$ and the supernatant saved. Subsequently, the supernatant was centrifuged at 100,000 $\mathrm{g}$ for $1 \mathrm{~h}$ at $4^{\circ} \mathrm{C}$ and the resultant pellet resuspended in K-HEPES buffer containing protease inhibitors. After measurement of the total protein concentration (Biorad Protein kit, Richmond, Calif.), $50 \mu \mathrm{g}$ of crude membrane protein was solubilised in SDS-buffer and loaded on $10 \%$ polyacrylamide gels. For some proteins (NHE3) the samples were heated at $80^{\circ} \mathrm{C}$ for 2 min before loading. The protein was transferred electrophoretically from the gel to PVDF membranes (Immobilon-P, Millipore, Bedford, Mass.). Membranes were blocked with $5 \%$ milk powder in TBS for $1 \mathrm{~h}$ and incubated with primary antibody: rabbit anti-human ATP6V0A4 1:10,000 [48]; rabbit anti-bovine ATP6V1B1 1:1,000, kind gift of K. Finberg, R.

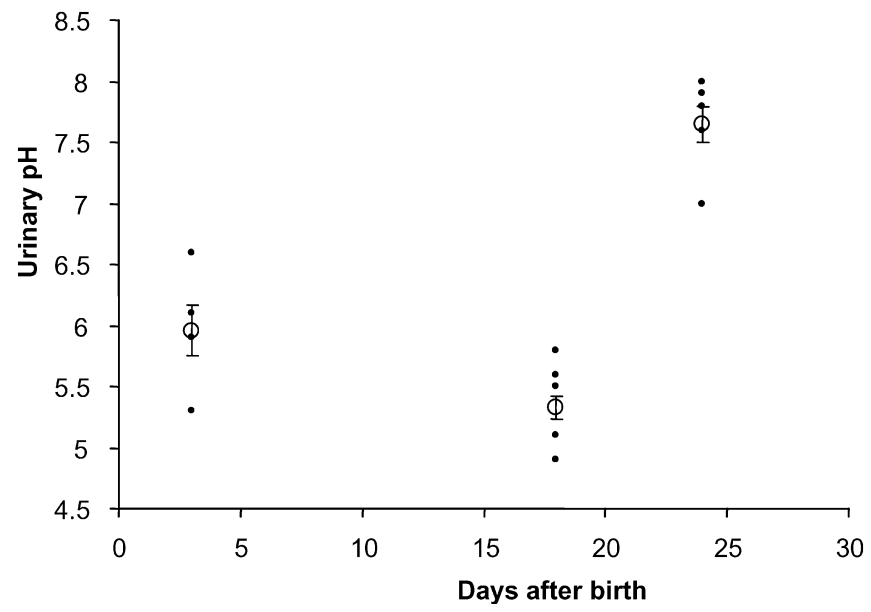

Fig. 1 Urinary $\mathrm{pH}$ of 3-, 18- and 24-day-old mice. Values presented as single values and means \pm SEM

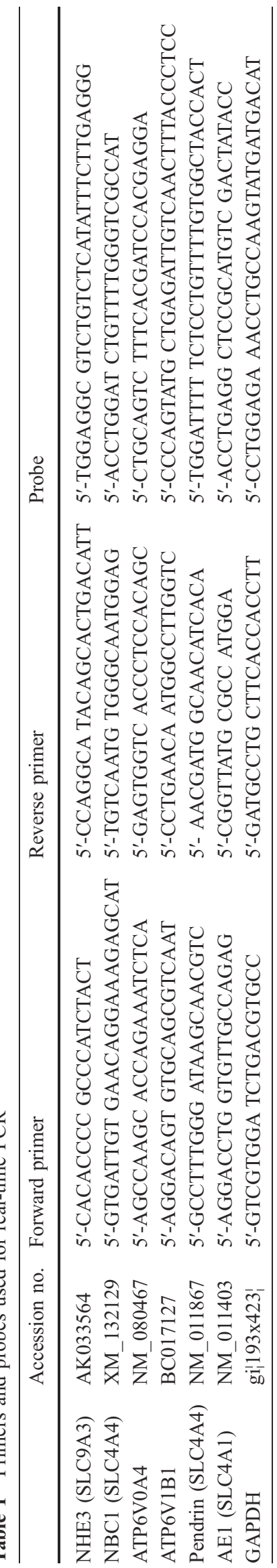


Table 2 Urine and blood values for 3-, 18- and 24-dayold mice. Values are presented as means \pm SEM. Urine and venous blood samples were collected and analysed immediately

${ }^{*} P<0.001,{ }^{2} P<0.05$, significant differences between 3 - and 18-day-old mice ${ }^{3}{ }_{P}<0.001,{ }^{4} P<0.05$, significant differences between 18 and 24-day-old mice

\begin{tabular}{|c|c|c|c|}
\hline & 3-day-old & 18-day-old & 24-day-old \\
\hline Urine $\mathrm{pH}$ & $6.0 \pm 0.2$ & $5.3 \pm 0.1 *^{2}$ & $7.7 \pm 0.2 * 3$ \\
\hline Urine creatinine $\left(\mathrm{mg} \mathrm{dl}^{-1}\right)$ & $15.4 \pm 1.1$ & $39.9 \pm 5.0 * 1$ & $49.2 \pm 5.8^{4}$ \\
\hline $\mathrm{K}^{+}\left(\mathrm{mmol} \mathrm{l}^{-1}\right)$ & $36.5 \pm 5.8$ & $47.9 \pm 0.4^{* 2}$ & $61.7 \pm 13.4$ \\
\hline $\mathrm{Na}^{+}\left(\mathrm{mmol} \mathrm{1} 1^{-1}\right)$ & $17.2 \pm 1.0$ & $29.9 \pm 5.6^{* 1}$ & $56.5 \pm 17.3 * 4$ \\
\hline $\mathrm{Cl}^{--}\left(\mathrm{mmol} \mathrm{1} \mathrm{l}^{-1}\right)$ & $38.6 \pm 10.3$ & $48.0 \pm 5.9$ & $85.5 \pm 24.6^{* 4}$ \\
\hline $\mathrm{FE}_{\mathrm{K}+}(\%)$ & ND & 11.6 & 3.4 \\
\hline $\mathrm{FE}_{\mathrm{Na}+}(\%)$ & ND & 0.2 & 0.1 \\
\hline $\mathrm{FE}_{\mathrm{Cl}-}(\%)$ & ND & 0.4 & 0.2 \\
\hline Serum creatinine $\left(\mathrm{mg} \mathrm{dl}^{-1}\right)$ & ND & $0.37 \pm 0.1$ & $0.11 \pm 0.01 *^{4}$ \\
\hline $\mathrm{K}^{+}\left(\mathrm{mmol} \mathrm{l}^{-1}\right)$ & ND & $4.0 \pm 0.1$ & $4.2 \pm 0.2$ \\
\hline $\mathrm{Na}^{+}\left(\mathrm{mmol} \mathrm{l}^{-1}\right)$ & ND & $144 \pm 0.4$ & $147.3 \pm 0.8^{* 4}$ \\
\hline $\mathrm{Cl}^{-}\left(\mathrm{mmol} \mathrm{l}^{-1}\right)$ & ND & $118.8 \pm 1.0$ & $120.0 \pm 1.4$ \\
\hline$n$ (animals) & 5 & 6 & 6 \\
\hline
\end{tabular}

Lifton, Yale University, USA [13]; rabbit anti-rat pendrin 1:5,000, kind gift of P.S. Aronson, Yale University, USA [24, 46]; rabbit antihuman AE1 1:3,000 (Chemicon, Temecula, Calif.); NBC1 1:5,000, kind gift of W. Boron, Yale University, USA; NHE3 1:5,000, kind gift of O. Moe, Dallas, Tex. [9]; and with monoclonal anti-actin $1: 2,500$ (42 kDa; Sigma) for either $2 \mathrm{~h}$ at room temperature or overnight at $4{ }^{\circ} \mathrm{C}$. Membranes were washed with TBS-Tween, blocked with $5 \%$ milk in TBS-Tween and the secondary antibody (donkey anti-rabbit conjugated to alkaline phosphatase 1:5,000, and sheep anti-mouse conjugated to alkaline phosphatase 1:5,000; Promega, Madison, Wis.) incubated for $1 \mathrm{~h}$. Membranes were again washed. Antibody binding was detected with a chemiluminescence substrate kit (CDP-Star, Roche Diagnostics, Indianapolis, Ind.), and than exposed to X-ray film (Kodak). The films were scanned and the intensity of the bands was analysed using Scion Image software and compared to the corresponding actin bands. For the calculation of expression ratios Gauss' law of error propagation was used and all results were tested for significance using the unpaired Student's $t$-test.

Immunohistochemistry

Male C57BL/6 J mice (3 days, 18 days and 24 days) were anaesthetised with ketamine-xylazine and perfused through the left ventricle with phosphate-buffered saline (PBS) followed by paraformaldehyde-lysine-periodate fixative [29]. Kidneys were removed and fixed in PLP overnight at $4^{\circ} \mathrm{C}$. Each kidney was sliced into 2-3 pieces, washed with PBS, left in $2.3 \mathrm{M}$ sucrose overnight for cryoprotection and then frozen in liquid nitrogen. Cryosections of $5 \mu \mathrm{m}$ were cut. Immunostaining was carried out as described [46]. Briefly, slides were rehydrated in PBS for at least $15 \mathrm{~min}$, then incubated with $1 \%$ SDS for 5 min, washed three times with PBS and incubated with PBS containing $1 \%$ bovine serum albumin for
Fig. 2 Relative mRNA abundance of NHE3, NBC1, the a4 (ATP6V0A4) and B1 (ATP6V1B1) subunits of the vacuolar $\mathrm{H}^{+}$-ATPase, pendrin and AE1 in kidneys from 3-, 18and 24-day-old mice. Relative abundance of mRNA was assessed by real-time PCR and calculated as described in Methods using GAPDH as internal reference. Significant increases were found for all mRNAs investigated (with the exception of ATP6V1B1) between day 3 and day 18 after birth, whereas no further significant changes were found between day 18 and day 24 after birth. *Significantly different from day $3(P<0.05)$
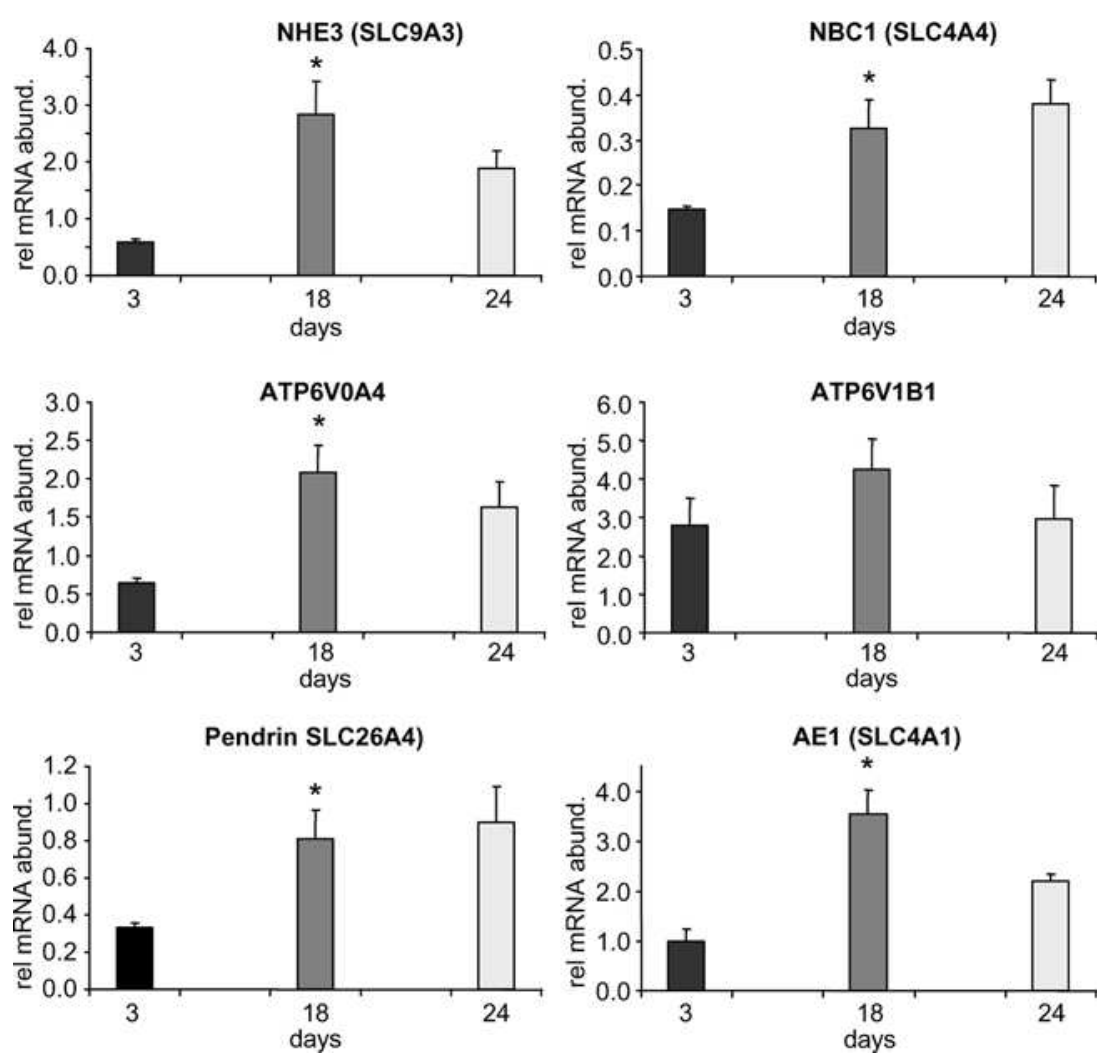
15 min prior to the primary antibody. The primary antibodies (the same as described for Western blotting) [rabbit anti-pendrin (1:500), rabbit anti-AE1 (1:200), rabbit anti-ATP6V0A4 $(1: 1,000)$, rabbit anti-ATP6V1B1 (1:300), NHE3 (1:5,000), NBC1 $(1: 5,000)$, goat anti AQP-2 (1:200)] were diluted in PBS $(150 \mathrm{mM} \mathrm{NaCl}, 10 \mathrm{mM}$ $\mathrm{KCl}, 40 \mathrm{mM} \mathrm{NaH} \mathrm{PO}_{4}, \mathrm{pH}$ 7.6) and applied for either $75 \mathrm{~min}$ at room temperature or overnight at $4{ }^{\circ} \mathrm{C}$. Sections were then washed twice for 5 min with hypertonic PBS (PBS+2.7\% NaCl), once with PBS, and incubated with the secondary antibodies [donkey antirabbit, Alexa 594 (1:1,000) and donkey anti-goat, Alexa 488 (1:400); Molecular Probes, Eugene Ore.], for $1 \mathrm{~h}$ at room temperature. Sections were again washed twice with high- $\mathrm{NaCl}$ PBS and once with PBS before mounting with VectaMount (Vector Laboratories, Burlingame, Calif.) diluted 1:1 in TRIS-HCl pH 8.9. Sections were viewed with a confocal microscope (Leica SP1 UV CLSM). Pictures were processed and assembled using Adobe Photoshop. Cell counts were performed for pendrin, AE1, ATP6V1B1, ATP6V0A4 and AQP2 on at least ten fields $(\times 400$ magnification) per kidney per animal, with three animals for each time point analysed $[41,46]$. Care was taken to observe similar regions in all kidneys.

\section{Results}

Urine and blood analysis

Urine and blood from 3-, 18- and 24-day-old C57BL/6 J mice were analysed for $\mathrm{pH}, \mathrm{K}^{+}, \mathrm{Na}^{+}, \mathrm{Cl}^{-}$and creatinine (Table 2, Fig. 1). Urine $\mathrm{pH}$ showed a significant acidification from day 3 to day 18 and alkalinisation at day 24 after birth. The fractional $\mathrm{K}^{+}$excretion declined from day 18 to day $24(11.6 \%$ to $3.4 \%)$. The concentration of electrolytes in serum and the fractional excretion of $\mathrm{Cl}^{-}$ and $\mathrm{Na}^{+}$were not altered from day 18 to day 24 after birth (Table 2).

Changes in relative mRNA abundance of acid-base transporters

Real-time PCR was used to assess the relative abundance of mRNAs of several transport proteins involved in renal acid-base transport to monitor developmental adaptation and maturation. Total RNA was extracted from kidneys of 3- $(n=5), 18-(n=5)$ and 24- $(n=4)$ day-old mice. GAPDH was taken as the internal reference gene and the ratio relative to GAPDH and to the expression of the gene of interest in adult kidney (12 weeks of age) was calculated. GAPDH mRNA levels did not change significantly between samples. In general, kidneys from 3-day-old mice showed lower relative mRNA levels, as compared to 18- and 24-day-old mice. Relative mRNA levels for NHE3 (SLC9A3), NBC1 (SLC4A4), pendrin (SLC26A4) and AE1 (SLC4A1) were lowest in kidneys from 3-day-old mice, with an approximately two- to fourfold increase at day 18 and no further significant increase at day 24 (Fig. 2). Similarly, relative mRNA levels of two kidneyspecific subunits of the vacuolar $\mathrm{H}^{+}$-ATPase, a4 (ATP6V0A4) and the IC-specific B1 (ATP6V1B1), were also increasing from day 3 to day 18 (Fig. 2).

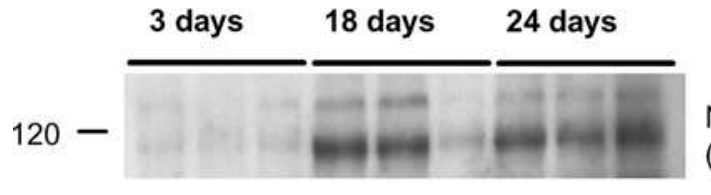

NHE3

(SLC9A3)
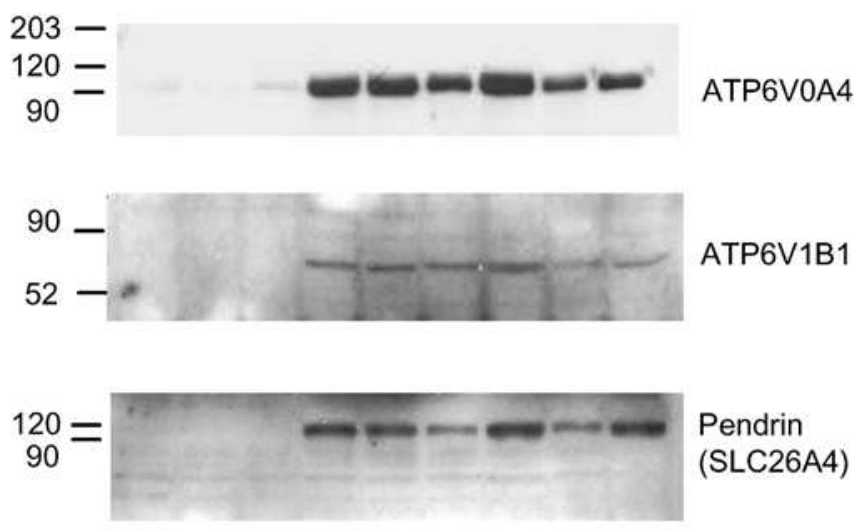

Pendrin

(SLC26A4)

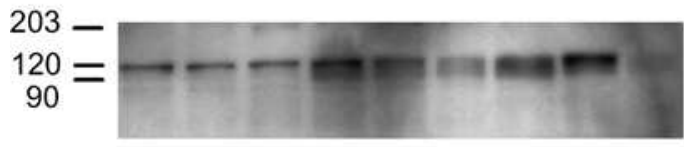

AE1

(SLC4A1)

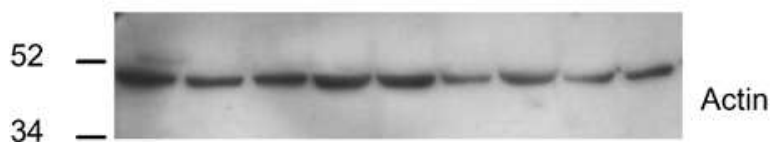

Fig. 3 Protein abundance of NHE3, the vacuolar $\mathrm{H}^{+}$-ATPase subunits ATP6V0A4 (a4), ATP6V1B1 (B1), the anion exchanger pendrin, the $\mathrm{Cl}^{-} / \mathrm{HCO}_{3}^{-}$exchanger $\mathrm{AE} 1$ and actin in kidneys from 3-, 18- and 24-day-old mice. The protein abundance of NHE3, ATP6V0A4, ATP6V1B1, pendrin, AE1 and actin was assessed by Western blot in crude membrane fractions prepared from whole kidneys. A several-fold increase in protein abundance was observed for all transport proteins from day 3 to day 18 after birth. Actin was tested on the same membranes after stripping to control for loading

\section{Changes in protein levels of acid-base transport}

Western blotting was used to assess changes in levels of acid-base transporter-related proteins and was expressed as ratio over actin and normalised against the expression ratio obtained for day 24 . In general, the expressed amount of all proteins investigated increased in parallel to the observations made on mRNA levels from day 3 to day 18 (Figs. 3, 4). The relative increase was parallel for both subunits of the vacuolar $\mathrm{H}^{+}$-ATPase and pendrin. Expression levels of NHE3 and AE1 did not increase significantly between day 18 and day 24. Data were not obtained for NBC1 because of the antibody.

Expression of proximal tubular acid-base transport proteins

Kidney sections from 3-, 18- and 24-day-old mice were stained to examine the localisation of transport proteins. In general, as an overview, only few proximal tubules in the cortex stained positive for the acid-base transporters 
Fig. 4 Relative changes in protein expression levels of NHE3, the vacuolar $\mathrm{H}^{+}$-ATPase subunits ATP6V0A4 (a4), ATP6V1B1 (B1), pendrin and AE1 in kidneys from 3-, 18- and 24-day-old mice. Relative changes in protein levels were calculated as a ratio over actin and expressed as percentages of the values obtained for 24 days. *Significantly different from day $3(P<0.05)$
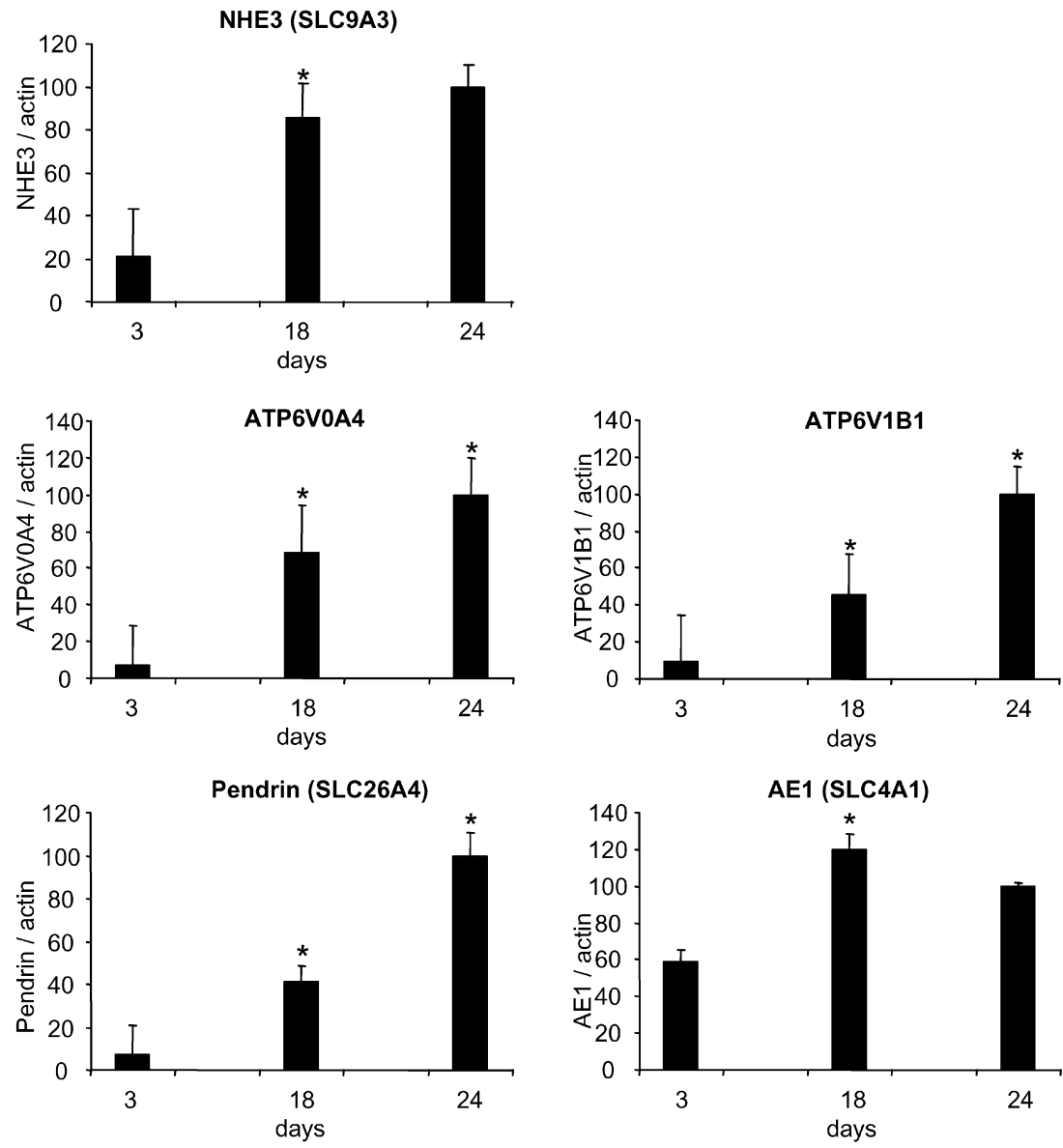

tested, indicating immaturity at 3 days after birth (data not shown). In addition, the staining for all transport proteins also appeared to be weaker at day 3 than at days 18 and 24 . In the proximal tubule of 3-day-old mice, there was very little NHE3 expression found according to the low expression levels seen by Western blotting (Fig. 5A). In contrast, many thick ascending limbs were stained for NHE3 (data not shown). Similarly, only few proximal tubules were seen with staining for the a4 vacuolar $\mathrm{H}^{+}$ATPase subunit and the basolateral $\mathrm{Na}^{+} / \mathrm{HCO}_{3}{ }^{-}$cotransporter NBC1 (Fig. 5C, E). Parallel with the increase in abundance of these proteins as demonstrated by Western blotting, more proximal tubules positive for NHE3, a4 and NBC1 were seen in kidneys of 18-day-old mice and the staining appeared more intensive (Fig. 5B, D, F). There was no further major difference noted in kidneys from 24day-old mice (data not shown).

\section{Abundance of type A and non-type A IC}

AE1/AQP2 and pendrin/AQP2 double-stainings were performed to assess changes in relative abundance and localisation of principal cells and different types of IC along the collecting duct. As a result of the difficulty in distinguishing between the CNT and CCD in kidneys from 3-day-old mice, we analysed CNT and CCD together. Several observations could be made: (1) the relative abundance of AQP2 expressing cells in the CCD decreased between day 3 and day 18 (Table 3); (2) AE1positive cells (type A IC) increased in all segments between day 3 and day 18 and remained constant between 18- and 24-day-old mice (Table 3, Fig. 6); (3) in the OMCD and IMCD, cells were noted being negative for both AQP2 and AE1 staining consistent with the phenotype of non-type A IC (Fig. 6B, D, Table 3); (4) in the $\mathrm{CCD}$, the relative abundance of pendrin-positive cells (non-type A IC) increased between 3- and 18-day-old mice but remained constant between 18- and 24-day-old mice (Fig. 7A, C) and (5) pendrin-positive cells were found in the OMCD and IMCD in 3-day-old mouse kidneys and less frequently in 18-day-old kidneys, but not in 24-day-old kidneys (Table 3, Fig. 7B, D). In adult kidney, pendrin-positive cells were found only in the CNT and CCD [35, 46, 49]. The appearance of pendrin-positive cells in OMCD and IMCD of 3-day-old mouse kidney is consistent with the finding of AE1- and AQP2-negative cells in the same segment at this developmental stage.

Subcellular localisation of the a4 and B1 vacuolar $\mathrm{H}^{+}$ATPase subunits

Staining of vacuolar $\mathrm{H}^{+}$-ATPase subunits confirmed the relative abundance of IC and principal cells as described. The staining of IC for B1 and a4 was categorised 
Fig. 5A-F Expression of the $\mathrm{Na} / \mathrm{H}^{+}$exchanger NHE3, the a4 (ATP6V0A4) vacuolar $\mathrm{H}^{+}$-

ATPase subunit and the $\mathrm{Na}^{+} /$

$\mathrm{HCO}_{3}{ }^{-}$cotransporter NBC1 in the proximal tubule in kidneys from 3- and 18-day-old mice.

Only few proximal tubules were found and stained for NHE3, a4 and NBC1 in kidneys from 3day-old mice, but the number of stained proximal tubules and the intensity of staining increased in kidneys from 18-day-old mice.

A, B Na${ }^{+} / \mathrm{H}^{+}$exchanger isoform 3 (NHE3). C, D a4 Vacuolar $\mathrm{H}^{+}$. ATPase subunit. $\mathbf{E}, \mathbf{F ~} \mathrm{Na}^{+} /$ $\mathrm{HCO}_{3}{ }^{-}$cotransporter (NBC1). $G$ glomerulum, $P T$ proximal tubule, $C C D$ cortical collecting duct. Original magnifications $\times 400-600$
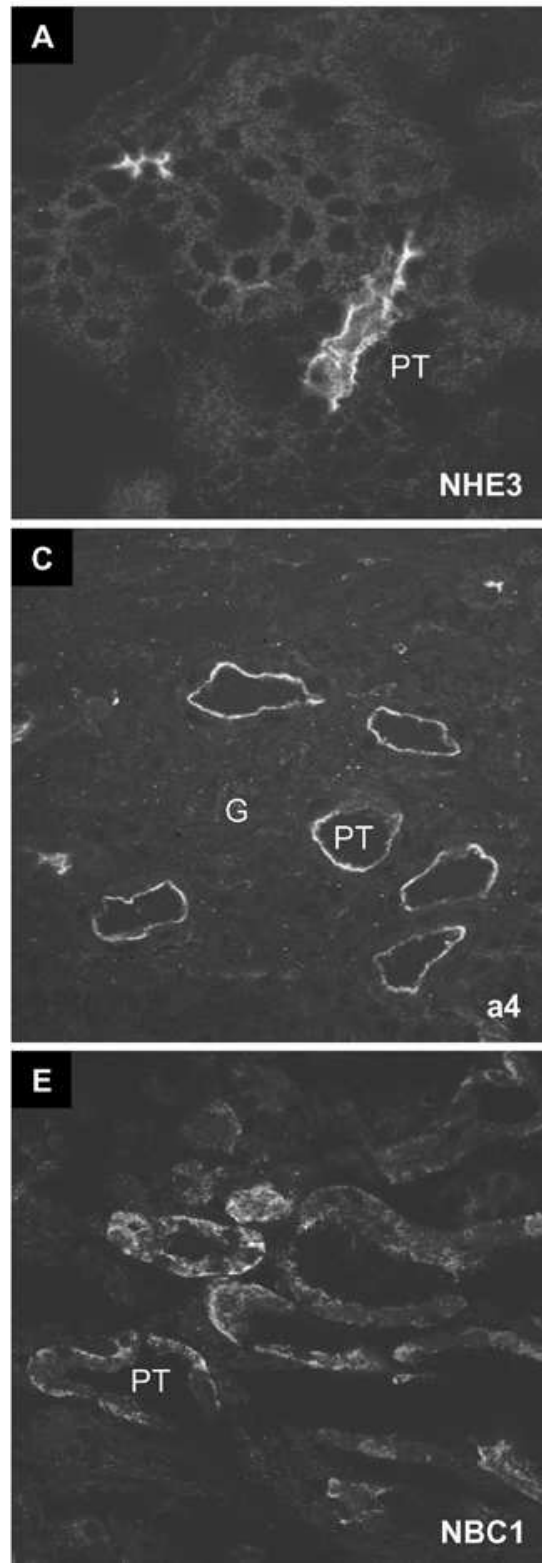

18 days
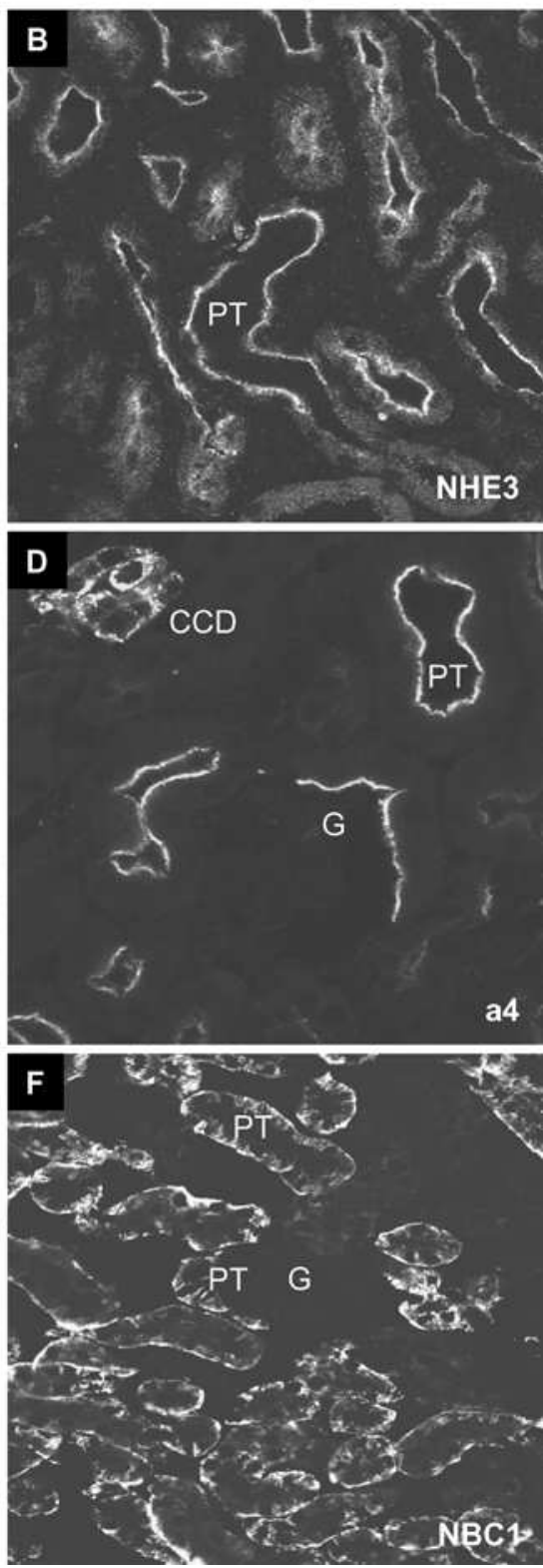

according to their predominant subcellular localisation as apical, subapical, diffuse, basolateral or bipolar as described previously (Tables 4,5$)[2,41]$. In the CCD, there was a decrease in the relative abundance of apically stained IC between 3 and 18 days, which remained constant between 18- and 24-day-old kidneys. Both basolateral and bipolar stainings were increased from day 3 to day 18, and remained unchanged between days 18 and 24 (Fig. 8A, B). Similar to the expression of pendrin in IC of the OMCD and IMCD, basolateral staining of a4 and B1 was found in IC in the OMCD and IMCD in 3- and 18-day-old mice, with no staining in 24-day-old mice (Fig. 8C-F, Tables 4, 5).

\section{Discussion}

After birth the kidney is not completely matured and excretory and reabsorptive functions are not fully developed as evident from animal models as well as from clinical measurements in newborns and infants $[6,10,11$, $28,51]$. In human newborns, small infants and in animal models (with the exception of rabbits) it was noted that plasma $\mathrm{HCO}_{3}{ }^{-}$levels and the renal threshold for $\mathrm{HCO}_{3}{ }^{-}$ are lower $[11,38]$ and that the renal capacity to excrete protons and acid-equivalents is only acquired at a later stage of development $[6,7,28]$. Accordingly, analysis of transport processes in whole organisms as well as in isolated brush border membranes or proximal tubules showed increases in activity of NHE3 [4, 5, 7], paralleled by increases in protein abundance [4]. Similar results have been obtained investigating $\mathrm{K}^{+}$secretion where renal $\mathrm{K}^{+}$ 
Table 3 Summary of the relative abundance of AE1-, pendrin- and AQP-2-stained cells along the collecting ducts of 3-, 18- and 24day-old mice. Type A intercalated cells (IC) were identified based on a positive staining for AE1, non-type A IC were identified based on a positive staining for pendrin, whereas principal cells were identified based on a positive staining for AQP-2. $C C D$ cortical collecting duct, $O M C D$ outer medullary collecting duct, IMCD inner medullary collecting duct

\begin{tabular}{|c|c|c|c|c|}
\hline Age & AQP2 positive/AE1 negative (\%) & AQP2 negative/AE1 positive (\%) & AQP2 negative/AE1 negative (\%) & $n$ (cells) \\
\hline \multicolumn{5}{|l|}{3 days } \\
\hline CCD & $75.4 \pm 2.0$ & $11.0 \pm 1.4$ & $13.6 \pm 1.2$ & 472 \\
\hline OMCD & $78.8 \pm 2.3$ & $16.6 \pm 1.8$ & $4.6 \pm 1.0$ & 374 \\
\hline IMCD & $81.3 \pm 1.8$ & $17.1 \pm 4.8$ & $1.6 \pm 0.7$ & 701 \\
\hline \multicolumn{5}{|l|}{18 days } \\
\hline CCD & $56.6 \pm 2.6^{* 1}$ & $21.2 \pm 1.5^{* 1}$ & $22.3 \pm 2.1 * 1$ & 361 \\
\hline OMCD & $68.1 \pm 2.0$ & $30.7 \pm 1.7 * 1$ & $1.3 \pm 0.7 *^{2}$ & 522 \\
\hline IMCD & $70.6 \pm 3.3$ & $28.4 \pm 3.7 *^{2}$ & $1.0 \pm 0.8$ & 640 \\
\hline \multicolumn{5}{|l|}{24 days } \\
\hline $\mathrm{CCD}$ & $50.9 \pm 3.1$ & $19.2 \pm 2.3^{* 4}$ & $29.9 \pm 2.9 * 4$ & 472 \\
\hline OMCD & $67.4 \pm 4.2$ & $32.7 \pm 4.2$ & 0 & 226 \\
\hline IMCD & $69.1 \pm 5.6$ & $30.9 \pm 5.6$ & 0 & 135 \\
\hline Age & AQP2 positive/pendrin negative (\%) & AQP2 negative/pendrin negative (\%) & AQP2 negative/pendrin positive (\%) & $n$ (cells) \\
\hline \multicolumn{5}{|l|}{3 days } \\
\hline $\mathrm{CCD}$ & $74.2 \pm 2.4$ & $8.5 \pm 0.9$ & $17.3 \pm 2.0$ & 392 \\
\hline OMCD & $56.3 \pm 4.9$ & $33.3 \pm 5.8$ & $10.5 \pm 2.6$ & 373 \\
\hline IMCD & $69.9 \pm 6.0$ & $17.2 \pm 7.4$ & $12.9 \pm 1.7$ & 465 \\
\hline \multicolumn{5}{|l|}{18 days } \\
\hline $\mathrm{CCD}$ & $55.0 \pm 2.0 * 1$ & $21.6 \pm 1.6^{* 1}$ & $23.5 \pm 1.3 *^{2}$ & 1,356 \\
\hline OMCD & $82.4 \pm 1.8^{* 1}$ & $15.1 \pm 1.6$ & $2.5 \pm 1.3 *^{2}$ & 309 \\
\hline IMCD & $66.1 \pm 10.8$ & $32.0 \pm 11.8$ & $1.9 \pm 1.5^{* 1}$ & 268 \\
\hline \multicolumn{5}{|l|}{24 days } \\
\hline CCD & $54.1 \pm 2.1 *^{4}$ & $18.6 \pm 2.2$ & $27.3 \pm 1.0$ & 1,154 \\
\hline OMCD & $80.8 \pm 1.3$ & $19.2 \pm 1.3$ & 0 & 323 \\
\hline IMCD & $84.3 \pm 4.2$ & $15.8 \pm 4.2$ & 0 & 114 \\
\hline
\end{tabular}

${ }^{*}{ }^{1} P<0.001, *^{2} P<0.05$, significant differences between 3 - and 18 -day-old mice

${ }^{*} P<0.001,{ }^{*} P<0.05$, significant differences between 18 - and 24 -day-old mice

Table 4 Summary of the relative abundance of IC and principal cells and the subcellular localisation of the $\mathrm{B} 1$ vacuolar $\mathrm{H}+$-ATPase subunits along the collecting ducts of 3-, 18- and 24-day-old mice. IC were identified based on a positive staining for B1 (ATP6V1B1) vacuolar $\mathrm{H}^{+}$-ATPase subunits and being negative for the principal cell $(P C)$-specific AQP2 water channel. The predominant subcellular localisation of B1 immunostaining was counted within each single IC.

\begin{tabular}{|c|c|c|c|c|c|c|c|c|}
\hline Age & IC (\%) & PC (\%) & Subapical (\%) & Apical (\%) & Basolateral (\%) & Bipolar (\%) & Diffuse (\%) & $n$ (cells) \\
\hline \multicolumn{9}{|l|}{3 days } \\
\hline $\mathrm{CCD}$ & $37.0 \pm 6.9$ & $63.0 \pm 6.9$ & $1.8 \pm 1.8$ & $59.9 \pm 8.0$ & $6.3 \pm 6.3$ & 0 & $32.1 \pm 7.9$ & 180 \\
\hline OMCD & $28.0 \pm 3.6$ & $72.0 \pm 3.6$ & 0 & $60.5 \pm 14.1$ & $13.9 \pm 9.0$ & $4.2 \pm 4.2$ & $21.4 \pm 6.7$ & 124 \\
\hline IMCD & $29.4 \pm 2.7$ & $70.6 \pm 2.7$ & $1.8 \pm 1.8$ & $78.9 \pm 3.5$ & $1.5 \pm 1.5$ & 0 & $17.8 \pm 4.9$ & 297 \\
\hline \multicolumn{9}{|l|}{18 days } \\
\hline IMCD & $25.2 \pm 4.4$ & $74.8 \pm 4.4$ & $4.7 \pm 4.7$ & $71.4 \pm 10.6$ & 0 & $1.0 \pm 1.0$ & $22.9 \pm 8.6$ & 210 \\
\hline \multicolumn{9}{|l|}{24 days } \\
\hline CCD & $39.9 \pm 1.7$ & $60.1 \pm 1.7$ & $1.4 \pm 1.0$ & $35.2 \pm 3.1$ & $18.6 \pm 2.9$ & $8.2 \pm 1.6$ & $36.7 \pm 2.9 * *$ & 1010 \\
\hline OMCD & $31.0 \pm 1.9$ & $69.0 \pm 1.9$ & $2.4 \pm 1.7$ & $51.4 \pm 6.2$ & $0 * *$ & 0 & $46.2 \pm 6.5^{* *}$ & 445 \\
\hline IMCD & $20.1 \pm 1.3$ & $79.9 \pm 1.3$ & $1.9 \pm 1.9$ & $77.5 \pm 5.3$ & 0 & 0 & $20.6 \pm 3.8$ & 777 \\
\hline
\end{tabular}

$* P<0.05$, significant difference between 3 - and 18-day-old mice

$* * P<0.05$, significant difference between 18 - and 24-day-old mice 
Fig. 6A-D Expression of AE1 in kidneys of 3- and 24-day-old mice. Kidneys were stained for the $\mathrm{Cl}^{-} / \mathrm{HCO}_{3}{ }^{-}$exchanger $\mathrm{AE} 1$, expressed only in type A intercalated cells, and AQP2, a marker for principal cells. A, C Only few AE1 positive cells (arrow) were found in the CCD at 3 days but their number increased at 24 days. B, D In the outer medullary collecting duct (OMCD) AE1 and AQP2 negative cells $\left(^{*}\right)$ were found in 3 day-old kidneys but not after 24 days after birth, indicating the disappearance of cells with characteristics of non-type A intercalated cells from the OMCD and inner medullary collecting duct (IMCD). Original magnifications $\times 400-600$

Fig. 7A-D Expression of pendrin in kidneys of 3- and 18day-old mice. Kidneys were stained for the $\mathrm{Cl}^{-}$/anion exchanger pendrin, expressed only in non-type A intercalated cells, and AQP2 as a marker for principal cells. A, B Pendrin expression in kidneys from 3 day-old mice showed apical localisation (arrow) in the CCD

(A) and also in the OMCD and IMCD (B). Some cells were negative for AQP2 and pendrin staining $(*)$ consistent with the type A intercalated cell phenotype. C, D In 18-day-old mouse kidney, pendrin staining was seen in the CCD (C) (arrows pendrin, *pendrin- and AQP2negative cells) similar that reported previously [35, 46, 49]. No staining for pendrin was visible in the IMCD (D) or OMCD. Original magnifications $\times 400-600$
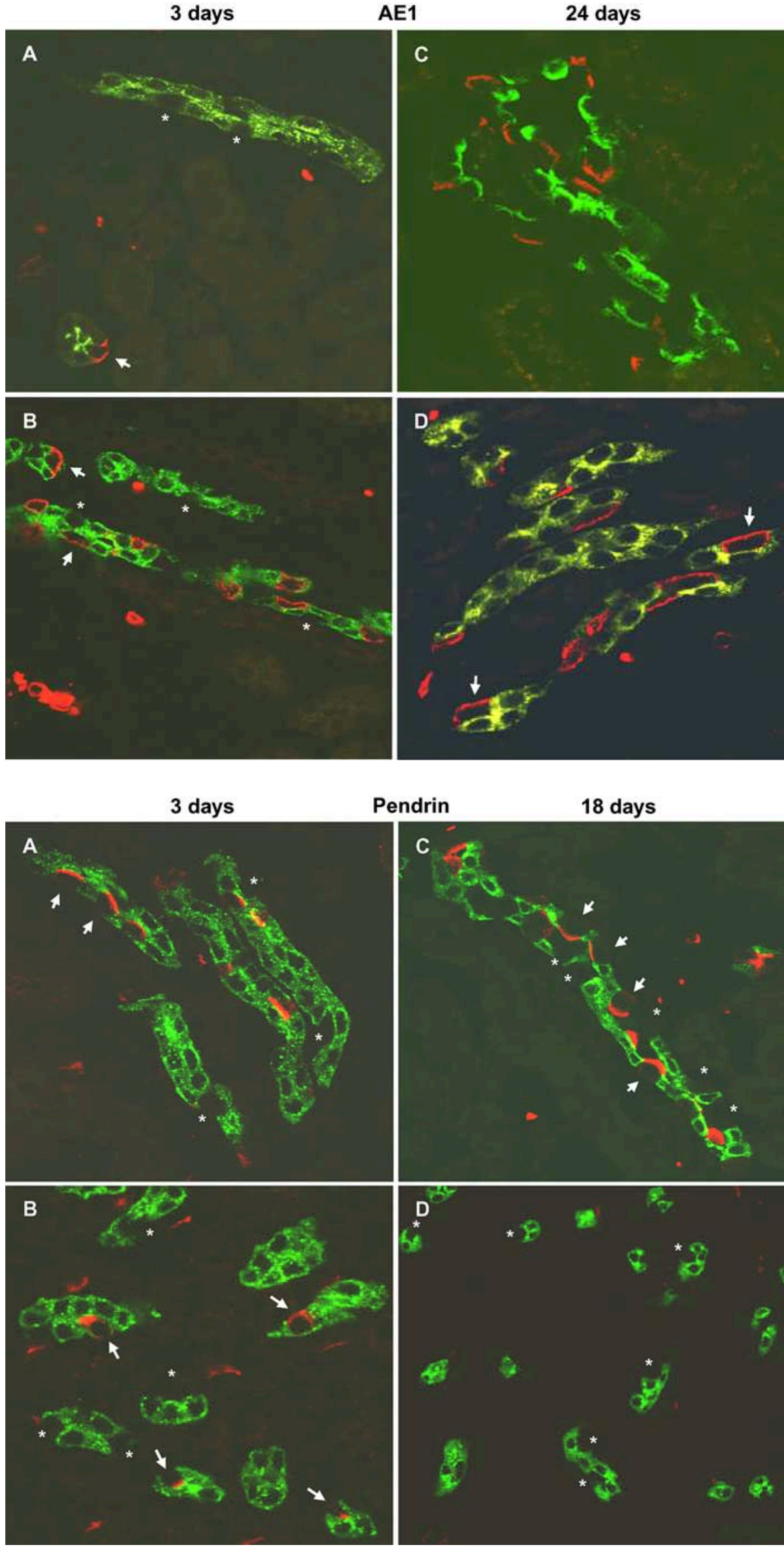
Fig. 8A-F Subcellular localization of the a4 (ATP6V0A4) and B1 (ATP6V1B1) subunits of the vacuolar $\mathrm{H}^{+}$-ATPase in intercalated cells of 3- and 24day-old mouse kidneys. Kidneys from 3- and 24-day-old mice were stained against AQP2 as a marker for principal cells and against either the intercalated cell-specific B1 vacuolar $\mathrm{H}^{+}$-ATPase subunit or the a4 subunit expressed along the entire nephron. The subcellular distribution of B1 in intercalated cells was similar to a 4 at all time points. A At 3 days most intercalated cells in the CCD showed a predominantly apical distribution of the B1 subunit. B In the CCD 24 days after birth, intercalated cells with a distribution of B1 subunits to the apical $(a)$ or basolateral $(b l)$ pole or both membranes (bipolar, $b p$ ) are found. $\mathbf{C}, \mathbf{E}$ In the OMCD and IMCD, intercalated cells with a clear basolateral staining (arrows) for the B1 subunit are found 3 days after birth. $\mathbf{D}, \mathbf{F}$ No intercalated cells with a pronounced basolateral staining for the B1 subunit are seen in the OMCD and IMCD of kidneys from 24-day-old mice. Original magnifications $\times 400$ 600
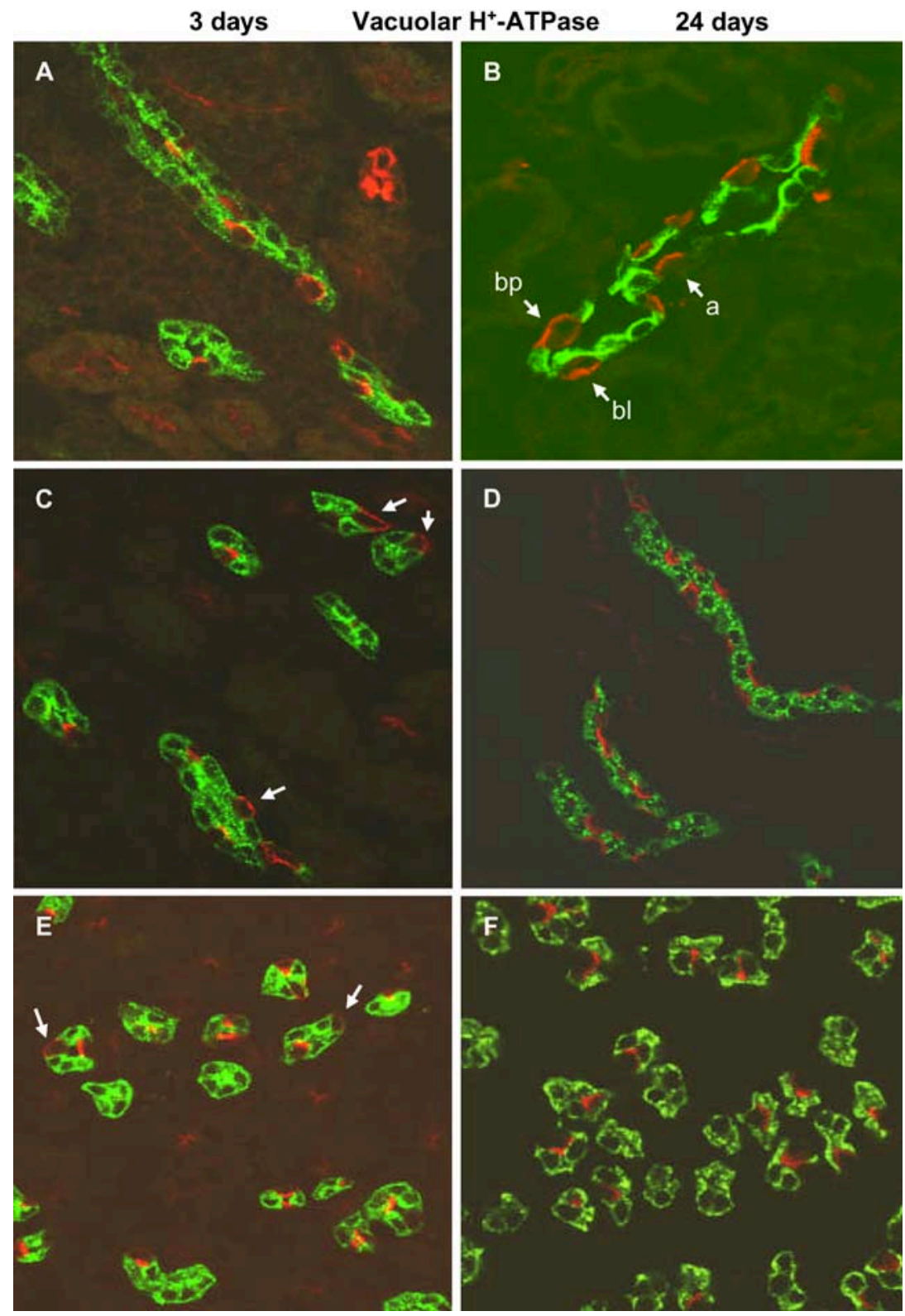

secretion increased together with mRNA or protein levels of ROMK or maxi-K channels [10, 51].

Our results indicate two major processes occurring mainly between the first two time points investigated, the increase in mRNA and protein expression levels from 3 to 18 days after birth and changes in the phenotype of IC in the collecting duct during the same period. The increase in mRNA and protein levels is paralleled by findings from other groups showing similar increases for NHE3 [4, 40], NaPi-IIa [44], the maxi-K channel [51] and carbonic anhydrase IV [50]. Taken together with the increased protein levels found for the a4 and B1 vacuolar $\mathrm{H}^{+}$ATPase subunits, AE1 and the stronger intensity of NBC1 staining, it appears that there is a co-ordinated increase in expression of proteins involved in the reabsorption of bicarbonate and excretion of protons. The increase in pendrin expression parallels the acquisition of bicarbonate secretion in the cortical collecting duct [30], a process that is thought to involve pendrin [35]. Also, a recent analysis of changes in global gene expression patterns in developing and maturating rat kidney revealed that mRNA levels of several proteins related to transport functions, such as SAT-1, all subunits of the $\mathrm{Na}^{+} / \mathrm{K}^{+}$-ATPase, 4F2hc, Na/PiIIa, NHE3, several members of the organic cation/anion transporter family, sugar transporters, and the ubiquitous c $(16 \mathrm{kDa})$ and $\mathrm{B} 2(58 \mathrm{kDa})$ subunits of the vacuolar $\mathrm{H}^{+}$ATPase, increased during these processes [42].

The second process, changes in IC phenotypes in the collecting duct, also suggests maturation of acid- and basesecretory functions in this nephron segment important for final urinary acidification. The total number of IC in the CCD increased significantly and the phenotype of IC showed clear alterations. The increase in IC number was evident only from the numbers presented in Table 3 but 
Table 5 Summary of the relative abundance of IC and principal cells and the subcellular localisation of the a4 vacuolar $\mathrm{H}^{+}$-ATPase subunits along the collecting ducts of 3-, 18- and 24-day-old mice. IC were identified based on a positive staining for the a4
(ATP6V0A4) vacuolar $\mathrm{H}^{+}$-ATPase subunits and being negative for the PC-specific AQP2 water channel. The predominant subcellular localisation of a4 immunostaining was counted within each single IC

\begin{tabular}{|c|c|c|c|c|c|c|c|c|}
\hline Age & $\mathrm{IC}(\%)$ & $\mathrm{PC}(\%)$ & Subapical(\%) & Apical(\%) & Basolateral(\%) & Bipolar(\%) & Diffuse(\%) & $n$ (cells) \\
\hline \multicolumn{9}{|l|}{3 days } \\
\hline CCD & $37.8 \pm 5.2$ & $62.2 \pm 5.2$ & $2.6 \pm 1.4$ & $60.1 \pm 6.7$ & $7.9 \pm 2.8$ & $10.9 \pm 4.1$ & $18.6 \pm 3.7$ & 510 \\
\hline OMCD & $16.4 \pm 1.4$ & $83.6 \pm 1.4$ & $4.5 \pm 3.2$ & $55.0 \pm 8.3$ & $10.4 \pm 7.0$ & 0 & $30.1 \pm 7.8$ & 366 \\
\hline IMCD & $20.7 \pm 1.9$ & $79.3 \pm 1.9$ & 0 & $80.6 \pm 5.6$ & $8.3 \pm 8.3$ & 0 & $11.1 \pm 4.8$ & 252 \\
\hline \multicolumn{9}{|l|}{18 days } \\
\hline CCD & $38.3 \pm 2.7$ & $61.6 \pm 2.7$ & $5.9 \pm 1.9$ & $44.1 \pm 4.4^{*}$ & $12.4 \pm 2.2$ & $6.7 \pm 1.5$ & $30.9 \pm 2.6^{*}$ & 1,451 \\
\hline OMCD & $22.9 \pm 3.3$ & $77.1 \pm 3.3$ & 0 & $35.5 \pm 9.1$ & $29.2 \pm 12.5$ & $5.4 \pm 3.7$ & $29.9 \pm 8.6$ & 205 \\
\hline IMCD & $22.0 \pm 1.2$ & $78.0 \pm 1.2$ & $15.4 \pm 4.4^{*}$ & $55.3 \pm 7.5^{*}$ & $8.6 \pm 3.2$ & $0.4 \pm 0.4$ & $20.3 \pm 3.5$ & 921 \\
\hline \multicolumn{9}{|l|}{24 days } \\
\hline CCD & $38.3 \pm 3.6$ & $61.7 \pm 3.6$ & $1.5 \pm 1.0 * *$ & $36.5 \pm 6.1$ & $15.1 \pm 3.8$ & $12.6 \pm 2.4 * *$ & $34.2 \pm 5.6$ & 599 \\
\hline OMCD & $25.7 \pm 1.0$ & $74.3 \pm 1.0$ & $4.9 \pm 3.3$ & $55.6 \pm 5.6$ & $0 * *$ & 0 & $39.6 \pm 5.8$ & 417 \\
\hline IMCD & $21.3 \pm 1.7$ & $78.7 \pm 1.7$ & $3.0 \pm 2.1 * *$ & $78.2 \pm 4.6^{* *}$ & $0 * *$ & 0 & $18.7 \pm 5.1$ & 566 \\
\hline
\end{tabular}

$* P<0.05$, significant difference between 3 - and 18-day-old mice

$* * P<0.05$, significant difference between 18 - and 24-day-old mice

not clear from data in Tables 4 and 5 where we had focused mainly on nephron segments expressing many cells positive for vacuolar $\mathrm{H}^{+}$-ATPase staining. Four major changes could be observed: (1) expression of IC in the OMCD and IMCD being positive for pendrin or expressing vacuolar $\mathrm{H}^{+}$-ATPase subunits on the basolateral membrane disappeared from day 3 to day 24 after birth, (2) the relative abundance of IC with apical staining of vacuolar $\mathrm{H}^{+}$-ATPases in the CCD decreased from day 3 to day 24 after birth, whereas the number of IC with basolateral or bipolar staining increased, (3) the number of IC in the CCD being positive for pendrin increased from day 3 to day 18 after birth, and (4) the number of AE1positive cells in all collecting duct segments also increased. Taken together these results indicate several changes in IC function during this period of maturation. First, there is evidence for the change of the IC phenotype along the collecting duct with the disappearance of IC from the OMCD and IMCD with characteristics of nontype A IC, namely expression of pendrin and basolateral vacuolar $\mathrm{H}^{+}$-ATPases. This observation is consistent with a previous examination of IC phenotype on the basis of expression of AE1 and vacuolar $\mathrm{H}^{+}$-ATPase distribution describing the occurrence and later disappearance of nontype A IC in rat kidney medulla [20]. The availability of pendrin as a specific marker for non-type A IC confirms now these previous results. Also the increase in AE1positive cells along the collecting duct is in agreement with a maturation of IC subtypes as described previously [15]. However, our results do not allow us to decide whether these non-type A IC are removed by apoptosis as suggested [21] or whether these findings may indicate a conversion of phenotype of IC in the OMCD and IMCD. Such plasticity between different subtypes of IC and even more between IC and principal cells has been suggested by several findings such as depletion from or appearance of more IC in the medulla in animals with carbonic anhydrase II [8] or AQP1 water channel [23] deficiencies, respectively. Our observations on pendrin expression and apical localisation of vacuolar $\mathrm{H}^{+}$-ATPases are also in agreement with the fact that urinary $\mathrm{pH}$ was lower in younger mice and that other groups have described a postnatal increase of cells with characteristics of non-type A IC, i.e. apical binding of peanut-lectin, and maturation of $\mathrm{HCO}_{3}{ }^{-}$secretion over the first weeks of life [30, 31, 36]. The fact that pendrin protein expression and basolateral localisation of vacuolar $\mathrm{H}^{+}$-ATPases is strongest at day 24 could also reflect the change in diet from mother milk to normal mouse chow which has been shown to provide a strong alkali load [26].

In summary, our findings demonstrate the parallel increase in expression of several transport proteins important for bicarbonate reabsorption in the proximal tubule and the fine regulation of final urinary acidification along the collecting duct. This increase in expression of transport proteins was paralleled by changes in IC subtype localisation and phenotype indicating the developmental disappearance of IC with characteristics of non-type A IC from the medulla and the full appearance of pendrin or AE1-positive IC in the CCD as well as acquiring the subcellular localisation of vacuolar $\mathrm{H}^{+}$-ATPases in IC as seen in adult kidney. These changes observed may underlay the final postnatal maturation of acid-base transport by the kidney but require further investigation to identify mechanisms governing and coordinating these processes.

Acknowledgement This study was supported by a grant from the Swiss National foundation (31-68318.02) to C.A.W. 


\section{References}

1. Alper SL, Natale J, Gluck S, Lodish HF, Brown D (1989) Subtypes of intercalated cells in rat kidney collecting duct defined by antibodies against erythroid band 3 and renal vacuolar $\mathrm{H}^{+}$-ATPase. Proc Natl Acad Sci U S A 86:5429-5433

2. Bastani B, Purcell H, Hemken P, Trigg D, Gluck S (1991) Expression and distribution of renal vacuolar proton-translocating adenosine triphosphatase in response to chronic acid and alkali loads in the rat. J Clin Invest 88:126-136

3. Baum M, Quigley R (1995) Ontogeny of proximal tubule acidification. Kidney Int 48:1697-1704

4. Baum M, Biemesderfer D, Gentry D, Aronson PS (1995) Ontogeny of rabbit renal cortical NHE3 and NHE1: effect of glucocorticoids. Am J Physiol 268: F815-F820

5. Baum M, Dwarakanath V, Alpern RJ, Moe OW (1998) Effects of thyroid hormone on the neonatal renal cortical $\mathrm{Na}^{+} / \mathrm{H}^{+}$ antiporter. Kidney Int 53:1254-1258

6. Baum M, Quigley R, Satlin L (2003) Maturational changes in renal tubular transport. Curr Opin Nephrol Hypertens 12:521526

7. Beck JC, Lipkowitz MS, Abramson RG (1991) Ontogeny of $\mathrm{Na} / \mathrm{H}$ antiporter activity in rabbit renal brush border membrane vesicles. J Clin Invest 87:2067-2076

8. Breton S, Alper SL, Gluck SL, Sly WS, Barker JE, Brown D (1995) Depletion of intercalated cells from collecting ducts of carbonic anhydrase II-deficient (CAR2 null) mice. Am J Physiol 269: F761-F774

9. Capasso G, Rizzo M, Pica A, Di Maio FS, Moe OW, Alpern RJ, De Santo NG (2002) Bicarbonate reabsorption and NHE-3 expression: abundance and activity are increased in Henle's loop of remnant rats. Kidney Int 62:2126-2135

10. Delgado MM, Rohatgi R, Khan S, Holzman IR, Satlin LM (2003) Sodium and potassium clearances by the maturing kidney: clinical-molecular correlates. Pediatr Nephrol 18:759767

11. Edelmann CM, Soriano JR, Boichis H, Gruskin AB, Acosta MI (1967) Renal bicarbonate reabsorption and hydrogen ion excretion in normal infants. J Clin Invest 46:1309-1317

12. Emmons C, Kurtz I (1994) Functional characterization of three intercalated cell subtypes in the rabbit outer cortical collecting duct. J Clin Invest 93:417-423

13. Finberg KE, Wagner CA, Stehberger PA, Geibel JP, Lifton RP (2003) Molecular Cloning and Characterization of Atp6v1b1, the Murine Vacuolar $\mathrm{H}^{+}$-ATPase B1-Subunit. Gene 318:25-34

14. Hamm LL, Alpern RJ (2000) Cellular mechanisms of renal tubular acidification. In: Seldin DW, Giebisch G (eds) The kidney: physiology and pathophysiology, 3rd edn. Lippincott Williams and Wilkins, Philadelphia, pp 1935-1979

15. Holthofer H (1987) Ontogeny of cell type-specific enzyme reactivities in kidney collecting ducts. Pediatr Res 22:504-508

16. Horster M (2000) Embryonic epithelial membrane transporters. Am J Physiol 279: F982-F996

17. Horster MF, Braun GS, Huber SM (1999) Embryonic renal epithelia: induction, nephrogenesis, and cell differentiation. Physiol Rev 79:1157-1191

18. Huber SM, Braun GS, Segerer S, Veh RW, Horster MF (2000) Metanephrogenic mesenchyme-to-epithelium transition induces profound expression changes of ion channels. Am J Physiol 279: F65-F76

19. Karashima S, Hattori S, Ushijima T, Furuse A, Nakazato H, Matsuda I (1998) Developmental changes in carbonic anhydrase II in the rat kidney. Pediatr Nephrol 12:263-268

20. Kim J, Tisher CC, Madsen KM (1994) Differentiation of intercalated cells in developing rat kidney: an immunohistochemical study. Am J Physiol 266: F977-F990

21. Kim J, Cha JH, Tisher CC, Madsen KM (1996). Role of apoptotic and nonapoptotic cell death in removal of intercalated cells from developing rat kidney. Am J Physiol 270: F575F592
22. Kim J, Kim YH, Cha JH, Tisher CC, Madsen KM (1999) Intercalated cell subtypes in connecting tubule and cortical collecting duct of rat and mouse. J Am Soc Nephrol 10:1-12

23. Kim YH, Kim J, Verkman AS, Madsen KM (2003) Increased expression of $\mathrm{H}^{+}$-ATPase in innermedullary collecting duct of aquaporin-1-deficient mice. Am J Physiol 285:F550-F557

24. Knauf F, Yang CL, Thomson RB, Mentone SA, Giebisch G, Aronson PS (2001) Identification of a chloride-formate exchanger expressed on the brush border membrane of renal proximal tubule cells. Proc Natl Acad Sci U S A 98:9425-9430

25. Kriz W, Kaissling B (2000) Structural organization of the mammalian kidney. In: Seldin D, Giebisch G (eds) The Kidney: physiology and pathopyhsiology, 3rd edn. Lippincott Williams and Wilkins, Philadelphia, pp 587-654

26. Lin SH, Cheema-Dhadli S, Chayaraks S, Chen CB, Gowrishankar M, Halperin ML (1998) Physiological disposal of the potential alkali load in diet of the rat: steps to achieve acid-base balance. Am J Physiol 274: F1037-F1044

27. Madsen KM, Clapp WL, Verlander JW (1988) Structure and function of the inner medullary collecting duct. Kidney Int 34:441-454

28. Manz F, Kalhoff H, Remer T (1997) Renal acid excretion in early infancy. Pediatr Nephrol 11:231-243

29. McLean IW, Nakane PK (1974) Periodate-lysine-paraformaldehyde fixative. A new fixation for immunoelectron microscopy. J Histochem Cytochem 22:1077-1083

30. Mehrgut FM, Satlin LM, Schwartz GJ (1990) Maturation of $\mathrm{HCO}_{3}^{-}$transport in rabbit collecting duct. Am J Physiol 259: F801-F808

31. Narbaitz R, Vandorpe D, Levine DZ (1991) Differentiation of renal intercalated cells in fetal and postnatal rats. Anat Embryol (Berl) 183:353-361

32. Nielsen S, DiGiovanni SR, Christensen EI, Knepper MA, Harris HW (1993) Cellular and subcellular immunolocalization of vasopressin-regulated water channel in rat kidney. Proc Natl Acad Sci U S A 90:11663-11667

33. Pfaffl MW (2001) A new mathematical model for relative quantification in real-time RT-PCR. Nucleic Acids Res 29:e45

34. Romero MF, Boron WF (1999) Electrogenic $\mathrm{Na}^{+} / \mathrm{HCO}_{3}$ cotransporters: cloning and physiology. Annu Rev Physiol 61:699-723

35. Royaux IE, Wall SM, Karniski LP, Everett LA, Suzuki K, Knepper MA, Green ED (2001) Pendrin, encoded by the Pendred syndrome gene, resides in the apical region of renal intercalated cells and mediates bicarbonate secretion. Proc Natl Acad Sci U S A 98:4221-4226

36. Satlin LM, Matsumoto T, Schwartz GJ (1992) Postnatal maturation of rabbit renal collecting duct. III. Peanut lectinbinding intercalated cells. Am J Physiol 262: F199-F208

37. Schuster VL, Fejes-Toth G, Naray-Fejes-Toth A, Gluck S (1991) Colocalization of $\mathrm{H}^{+}$-ATPase and band 3 anion exchanger in rabbit collecting duct intercalated cells. Am J Physiol 260: F506-F517

38. Schwartz GJ, Evan AP (1983) Development of solute transport in rabbit proximal tubule. $\mathrm{I}$. $\mathrm{HCO}_{3}{ }^{-}$and glucose absorption. Am J Physiol 245: F382-F390

39. Schwartz GJ, Olson J, Kittelberger AM, Matsumoto T, Waheed A, Sly WS (1999) Postnatal development of carbonic anhydrase IV expression in rabbit kidney. Am J Physiol 276: F510 F520

40. Shah M, Gupta N, Dwarakanath V, Moe OW, Baum M (2000) Ontogeny of $\mathrm{Na}^{+} / \mathrm{H}^{+}$antiporter activity in rat proximal convoluted tubules. Pediatr Res 48:206-210

41. Stehberger P, Schulz N, Finberg KE, Karet FE, Giebisch G, Lifton RP, Geibel JP, Wagner CA (2003) Localization and regulation of the ATP6V0A4 (a4) vacuolar $\mathrm{H}^{+}$-ATPase subunit defective in an inherited form of distal renal tubular acidosis. J Am Soc Nephrol 14:3027-3038

42. Stuart RO, Bush KT, Nigam SK (2001) Changes in global gene expression patterns during development and maturation of the rat kidney. Proc Natl Acad Sci U S A 98:5649-5654 
43. Teng-umnuay P, Verlander JW, Yuan W, Tisher CC, Madsen KM (1996) Identification of distinct subpopulations of intercalated cells in the mouse collecting duct. J Am Soc Nephrol 7:260-274

44. Traebert M, Lotscher M, Aschwanden R, Ritthaler T, Biber J, Murer H, Kaissling B (1999) Distribution of the sodium/ phosphate transporter during postnatal ontogeny of the rat kidney. J Am Soc Nephrol 10:1407-1415

45. Van der Heijden AJ, Guignard JP (1989) Bicarbonate reabsorption by the kidney of the newborn rabbit. Am J Physiol 256: F29-F34

46. Wagner CA, Finberg KE, Stehberger PA, Lifton RP, Giebisch GH, Aronson PS, Geibel JP (2002) Regulation of the expression of the $\mathrm{Cl}^{-}$/anion exchanger pendrin in mouse kidney by acid-base status. Kidney Int 62:2109-2117

47. Wagner CA, Geibel JP (2002) Acid-base transport in the collecting duct. J Nephrol [Suppl 5]:S112-127
48. Wagner CA, Lukewille U, Valles $\mathrm{P}$, Breton S, Brown D, Giebisch GH, Geibel JP (2003) A rapid enzymatic method for the isolation of defined kidney tubule fragments from mouse. Pflugers Arch 446:623-632

49. Wall SM, Hassell KA, Royaux IE, Green ED, Chang JY, Shipley GL, VerlanderJW (2002) Localization of pendrin in mouse kidney. Am J Physiol 284: F229-F241

50. Winkler CA, Kittelberger AM, Watkins RH, Maniscalco WM, Schwartz GJ (2001) Maturation of carbonic anhydrase IV expression in rabbit kidney. Am J Physiol 280: F895-F903

51. Woda CB, Miyawaki N, Ramalakshmi S, Ramkumar M, Rojas R, Zavilowitz B, Kleyman TR, Satlin LM (2003) Ontogeny of flow-stimulated potassium secretion in rabbit cortical collecting duct: functional and molecular aspects. Am J Physiol 285: F629-F639 